\title{
MORAL, POLITICS AND METHOD: THE
}

\author{
INFLUENCE OF RONALD DWORKIN'S
}

PHILOSOPHY ON THE BRAZILIAN SUPREME

COURT

Luciano Del Monaco

Pontifical Catholic University of São Paulo - PUC/SP.

Contact: lucianomonaco@gmail.com.

Nuria López

Pontifical Catholic University of São Paulo - PUC/SP.

Contact: nuria.lcs@gmail.com

Abstract: This article analyses the use of Ronald Dworkin's philosophy by the Brazilian Supreme Court. After the Constitution of 1988, the Supreme Court gained a new and broader role in Brazilian political scene. At this time, the work of Ronald Dworkin (and its Brazilian editions) became popular and served as justification for four of the most important cases on the Supreme Court: the fidelity of Congresist's members on their Political Party; the permission of embryonic stem cells research; the unconstitutionality of press regulation; and the homosexual civil union. Dworkin's philosophy is a part of the changingrole of the Supreme Court in Brazil. This article offers a demonstration of the use of this philosopher in this in-progress process.

Keywords: Ronald Dworkin - Brazilian Supreme Court - Legal Interpretation.

\section{BRIEFLY INTRODUCTION ABOUT BRAZILIAN SUPREME COURT'S ROLE AND DWORKIN'S WORK INFLUENCE IN IT}

This paper will study how the work of the late Ronald Dworkin is being used by the Supreme Court of Brazil, its impact on all the cases that it was applied and possible prognosis regarding future developments. There are just four cases using Dworkin's work in Brazilian Supreme 
Court: the Case of Congressist's Fidelity on their Political Party ${ }^{1}$; Case of Constitutionality of Biosecurity Law/Permission of embryonic stem cells research ${ }^{2}$; Case of Unconstitutionality of Press Regulation ${ }^{3}$; and the Case of Homosexual Civil Union ${ }^{4}$.

It is also needed to advise before-hand that we will also provide explanation on the political and judiciary system when needed in order to clarify how and why the Brazilians Justices turned their attention to Dworkin. A very interesting idiosyncrasy of the Supreme Court of Brazil is that, despite ruling an incredible number of cases every year (a total amount of 90.058 decisions issued in $2012^{5}$ ), Dworkin was quoted only in a handful number of cases (seven in total, three of them regarding the Case of Congressist's). However, all of them can be considered hard cases $^{6}$, and while small in numbers, they have serious proportions, both on political and juridical aspects. The stated above is, of course, relevant - but is not enough to explain the whole picture.

The following statement is somewhat trivial (in the American judicial tradition, at least), that the Supreme Court is a third political arena $^{7}$. Looking at the matter by a historic point of view the political use of the judiciary lies at the roots of the theory of judicial review.

1 Mandado de Segurança n²6602/DF, Partido Popular Socialista - PPS x Presidente da Câmara dos Deputados, Relator Ministro Eros Grau; Mandado de Segurança $n^{\circ}$ 26603/DF, Partido da Social Democracia Brasileira - PSDB x Presidente da Câmara dos Deputados, Relator Ministro Celso de Mello, and Mandado de Segurança $n^{\circ}$ 26604/DF, Partido Democratas - DEM x Presidente da Câmara dos Deputados, Relatora Ministra Carmen Lúcia, all judged on 07/03/2007. Full Sentences respectively available at: http://redir.stf.jus.br/ paginadorpub/paginador.jsp?docTP=AC\&docID=555539; http://redir.stf.jus.br/paginadorpub/ paginador.jsp?docTP=AC\&docID=570121; http://redir.stf.jus.br/paginadorpub/paginador. jsp?docTP=AC\&docID $=552057$.

2 Ação Direta de Inconstitucionalidade n ${ }^{\circ} 3510$, Procurador Geral da República x Presidente da República, Relator Ministro Ayres Britto , judged on 05/29/2008. Full Sentence available at: http://redir.stf.jus.br/paginadorpub/paginador.jsp?docTP=AC\&docID=611723

3 ADPF nº 130, Partido Democrático Trabalhista - PDT x Presidente da República e Congresso Nacional, Relator Ministro Ayres Britto, judged on 04/30/2009. Full Sentence available at: http://redir.stf.jus.br/paginadorpub/paginador.jsp?docTP=AC\&docID=605411

4 Ação de Descumprimento de Preceito Fundamental $n^{\circ} 132$, Governador do Estado do Rio de Janeiro, Relator Ministro Ayres Britto and Ação Direta de Inconstitucionalidade $\mathrm{n}^{\mathrm{o}}$ 4277, Procuradora Geral da República, Relator Ministro Ayres Britto, all judged on 04/04/2011. Full Sentences respectively available at: http://redir.stf.jus.br/paginadorpub/ paginador.jsp?doc $\mathrm{TP}=\mathrm{AC} \& \operatorname{docID}=628633$; $\mathrm{http}: / /$ redir.stf.jus.br/paginadorpub/paginador. jsp?docTP $=\mathrm{AC} \& \operatorname{doc} I \mathrm{D}=628635$.

5 Information from the website of the Supreme Court, link: http://www.stf.jus.br/portal/cms/ verTexto.asp? servico=estatistica\&pagina $=$ decisoesgeral

6 Most of these 90.058 cases are very straight-forward, workaday decisions, they are ruled by Supreme Court due to the characteristics of the Brazilian appeal system.

7 Considering that both Brazil and United States of America have a lower house and a higher house (first and second arenas). 
Despite the historic explanation, the fact is that the Supreme Court in Brazil (which was created in 1891) never had political influence nor held a public discussion - during most of its life the Supreme Court was a methodical, technical and powerless institution ${ }^{8}$. The Court was so much a non-factor that Justice Aliomar Baleeiro published in 1968 a book entitled "The Supreme Court, another unknown stranger"" (free translation). Expressions like "the political agenda of the Court" were simply non-existent in Brazil at all.

The turning point was the Constitution of 1988 (promulgated after twenty-four years of a military dictatorship) and the return to a democratic system of government and a relative well balanced power distribution between the institutions. Hand-to-hand with this frame was the Constitution itself, a very prolific text (a total of $347 \operatorname{articles}^{10}$ ) filled with an incredible range of rights. After a dictatorship, a democracy is put in place and the new Constitution means for the Supreme Court to implement these rights. That was a fertile compound to develop a political agenda.

An institutional change was trigged by the Constitution, and this kind of evolution takes some time, the Court needed to renew itself and its composition, bringing to the hall a new generation of Justices. We could pinpoint the end of the transition at the year of 2003, when Justice Moreira Alves retired after twenty eight years of service, he was well known by his technical and conservative attitude, being averse to an interpretation of the Constitution which stranded from the legal aspects and delved into the political field.

In short, after this whole process the Court found itself with enough freedom to act, means to act, finally a place (although small in the beginning) in the public opinion ${ }^{11}$ - and, the most important, a mission - "to protect and to abide the Constitution" 12 ". Needless to say, the Brazilians Justice took to themselves the task of shaping the Constitution in a manner consistent with their political, ideological and juridical ways of thought.

A remarkable 'discovery' of this paper revolves around the cases where the work of Ronald Dworkin was quoted. We perceived that

8 We should not simply blame the Court, it is need to highlight that during the whole twentieth century the Brazilian political frame was filled with dictatorships and some brief periods of democracy between them.

9 Original title in Portuguese: "O Supremo Tribunal Federal, esse outro desconhecido".

10 There are very important matters in the Constitution, of course, but there also some silly ones, like the article 242, $\$ 2$ "The Pedro II School, localized in the city of Rio de Janeiro, will still be kept in the union possession" (the Union does not have any other schools) [free translation]. 11 Since the passing of the Law $n^{\circ} 10.461 / 2002$ all the hearings of the Supreme Court were televised live (after this law other higher courts in Brazil started their own television feed).

12 Reference in Brazilian Constitution: article 102, caput. 
more than being hard cases ${ }^{13}$ - they were cases which are to be solved in the Legislative, by a public and democratic discussion. However, they were not discussed there and remained unsolved for a long period of time, 'forgotten' both by the Lower and Higher Chambers. Or there were laws that found strong opposition in the Legislative and needed to be stamped by the Court. In one way or another, when the Justices of the Supreme Court had the chance to solve these questions, they did declaring the unconstitutionality of norms, its constitutionality, giving it an interpretation sometimes contra legem (against the normative text) to conform the law to the Constitutional principles.

It is unnecessary to highlight that by this process the Supreme Court delve in the competence of the Legislative, taking the burden of solving difficult and highly unpopular matters off the back of the Legislative. This process of progressive emptying of the Legislative (which turns a blind eye to the competences transgressions performed by the Court), also known as democratic crisis, is not new, both worldwide and in Brazil - as pointed out by Oscar Vilhena Vieira on his paper about the growing power of the Supreme Court:

A second point of view sees an ampliation of the Law's and Judiciary's roles as result of the retraction of the representative system and its inability of comply the promises of justice and equality, inherent to the democratic ideal and incorporated in the contemporary constitutions. At this point, there is an appeal to the judiciary as it is the last guardian of democratic ideals. It causes, evidently, a democratic situation, for, while trying to fulfill the lacks left for the representative system, judiciary only contributes to the ampliation of the democracy authority's crisis itself. ${ }^{14}$

Also, another helpful information is that the translation of Dworkin's work to Portuguese is very recent, as to be shown further in this paper, which can also explain the lateness of his arrival in Brazil. For example, the Brazilian edition of Taking rights seriously [Levando os direitos a sério] dates from 2002; Life's dominion [O domínio da vida] dates from 2003; and Sovereign Virtue [Virtude Soberana] dates from 2005. Nevertheless, according to the data of one of the most important congress ${ }^{15}$ in the country, Dworkin was quoted 977 times in 120 different works, indicating that despite being something new he also is subject of attention and study in Brazil. It did not take too long until it reach the Supreme Court.

13 Cases which have complex and difficult solution and can be solved in a multitude of ways, often one of them contradicts and exclude the other.

14 Oscar Vilhena, "Supremocracia" in Revista Direito GV, no08, Jul-Dec/2008, p.443.

15 CONPEDI - IndexaDireito. Link: http://150.162.138.7/authors/report?page $=4 \&$ size $=50$ 


\section{CASE OF CONGRESIST'S FIDELITY ON THEIR OWN POLITICAL PARTY}

This political question started on Brazilian Congress and ended up (as it usually does) on the tariff trial of Supreme Court. The problem is that many Congresists (Deputies or Senators) were voting against their own Political Party directions. In Brazil the election for Congress demands a Party filiation. There is no such thing as an independent candidature, as there is in the US. Each vote goes to the Party, then it is calculated a coefficient for each Chair, that are distributed to the Parties with more votes. But then, inside the Parties, the Chairs are distributed between the candidates with more votes. It is usual that a candidate with more votes in a Party with fewer votes is not elected (because his Party was not able to get enough Chairs), while a candidate with few votes in a Party with plenty votes is elected. This system encourages individual campaigns during the elections; Parties usually include popular/famous people as candidates - to help the Party to get a good colocation in the coefficient calculus. But then, when they are already in Congress, they do not want to follow the Parties directions. Its votes are subject to all kind of games - lobbies (that in Brazil are not regulated); personal interests; own electoral bases interests, etc.

The matter was first lead to the Electoral Superior Court (Superior Tribunal Eleitoral - TSE), that also has a consulter competence. The Parties wanted to know if it was possible for a Congress Member to vote against his Party direction's, since the Chair belongs to the Party (according to our constitutional system); or if Congress Members can vote whatever they please, since the Party get Chairs because of the votes the candidates receive (according to the same constitution system). Also, to make the question more complex, Brazilian Constitution literally lists the hypothesis of Chair loss - and this was not one of them.

The Electoral Superior Court decided that the Congress Chairs belongs to the Party, that could expulse the disloyal Member in that hypothesis. The idea of the Court was to privilege the Parties (and so, the political programs) despite of the individuals voted for the people.

Of course, the case reached the Supreme Court - it was judged in the $\mathrm{MS} \mathrm{n}^{\circ}$ 266602/DF; 26603/DF and 26604/DF, on 07/03/2007. In this case the decision of Electoral Superior Court was confirmed by a "moral interpretation of the Constitution", as stated in the vote of Justice Menezes Direito ${ }^{16}$. He claimed that the interpretation of the Constitution by the Supreme Court sometimes imposes an "objective definition of the extension of a specific legal dispositive or the value system that present, and cannot be taken just in the historical, grammatical, systematical

16 Full Sentence, pp. 48-50. 
meaning" of the traditional method of interpretation. And for a broader interpretation that "propitiate an adequate presence of the Constitution in the social life" he uses Dworkin's moral reading:

It is not for other reason that Ronald Dworkin faces what he calls the moral reading of American Constitution. Enhancing that "of course the moral reading is not appropriate to everything a constitution contains" (extracted of the original edition, p. 17), Dworkin shows that many times history does not reveal nothing that help us to know what the authors of the Constitutions wanted to say when established general principles ${ }^{17}$.

Justice Menezes Direito was searching for a justification for a moral reading, or more precisely, a political reading of the Constitution. Both judicial results - let the Parties or let the Congressists have the Chair - were legally possible. Choosing the Parties was, in a certain point, a political decision to favor the Parties structures. In Brazil, as the Judiciary is seen as a technical institution, it is necessary to justify a political decision-making giving it an academic, scientific argumentation. Dworkin was very helpful for the Justice who, by quoting him, said that "the moral reading do not dispense the personal conviction of each interpreter". And then uses Dworkin as scientific argumentation:

I not only concede but emphasize that constitutional opinion is sensitive to political conviction. Otherwise, as I said, we would not be able to classify jurists as conservatives or moderate or liberal or radical with even the success we have. The question is rather whether the influence is disreputable. Constitutional politics has been confused and corrupted by a pretense that judges (if only they were not so hungry for power) could use politically neutral strategies of constitutional interpretation. Judges who join in that pretense try to hide the inevitable influence of their own convictions even from themselves, and the result is a costly mendacity. The actual grounds of decision are hidden from both legitimate public inspection and valuable public debate. The moral reading

17 All the translations from Portuguese are made by the authors. 
offers different counsel. It explains why fidelity to the Constitution and to law demands that judges make contemporary judgments of political morality, and it therefore encourages an open display of the true grounds of judgment, in the hope that judges will construct franker arguments of principle that allow the public to join in the argument. (...) The moral reading insists, however, that this influence is not disreputable, so long as it is openly recognized, and so long as the convictions are identified and defended honestly, by which I mean through proper arguments of principle not just thin slogans or tired metaphors. (extracted of the original edition, p.46)

The Justice found this argument fascinating and considered that the "interpreter cannot be distant of human reality in which the interpretation is done, and that is sufficient to take it off the Science or the technic, being the judicial decision" [and here quoting Dworkin again] "proposes that we all-judges, lawyers, citizens- interpret and apply these abstract clauses on the understanding that they invoque moral principles about political decency and justice" (extracted of the original edition, $p .2$ ).

He also pointed that a moral (or a political) reading was necessary in this case to improve the normative force of the Constitution, in reference to the work of Konrad Hesse [1959] with this title. Saying that a specific interpretation gives or optimize the normative force of some constitutional norm became a very popular argument in Brazilian Courts. It came along with a principiology thesis as Dworkin's. Justice Menezes Direito finished his vote by stating that he "ponderate what best meets principles and fundamental values printed in the Constitution itself".

Thereby, even that the hypothesis in judgment was not listed by the Constitution as a case of Chair loss by Congressmen, the Supreme Court, agreeing with Justice Menezes Direito made the Congressist's Fidelity also a case of loss of electoral mandate - changing deeply the political game in the whole Legislative.

\section{CASE OF EMBRYONIC STEM CELL RESEARCH OR THE CONSTITUTIONALITY OF BRAZILIAN BIO- SECURITY LAW}

The possibility that embryonic stem cell research can provide significant scientific breakthroughs to mankind is undeniable, but it is also a highly questionable decision when we include religious and 
moral questions into the equation. In this case, it was sanctioned the Law 11.105/2005 (Bio-security Law) approving research utilizing embryonic stem cells and it was immediately brought to the attention of the Court (the ruling was passed in 2007).

The Attorney General of Justice ${ }^{18}$ proposed the lawsuit, arguing the unconstitutionality of the fifth article, which, if was ruled out, would render the Law completely ineffective. More than a discussion of Constitutional Law, the entire discussion in the Court was a clash of more liberal and conservative Justices, the first trying to preserve the Law as it was enacted by the Legislative and the latter trying to insert in the text forms of restriction regarding research utilizing embryonic stem cells.

In the end, by a thin margin (six votes to five), the Court decided to sustain the Law without any addition or restriction.

At first glance, it would seem that the case described was a normal discussion of unconstitutionality, yet it was a very atypical one. On a regular basis, a Law is passed after a relative consensus about its matter is agreed on, in this case that did not happened ${ }^{19}$. The Law was passed but the discussion was nowhere near the end - the very substance of the Law was discussed in the Court, rendering the discussion in the Legislative useless (by doing it all again), thus invading the competence of the Legislative.

As the other cases above, this was another situation where the Supreme Court had a very major and decisive role, in the end of the day the Law's fate rested upon the political and moral positions of the Justices. We can throw the Legislative through the window then. Is there any reason to have a forum of public discussion if the final decision is taken by a Court where the Legislative point of view has no impact?

Having depict the case, is high time to investigate why the work of Ronald Dworkin was used, and its place in the arguments brought to the discussion.

Justice Ayres Britto was the first to vote, and, as said before, he disregards the previous state of the discussion. It is needed to say that he voted to sustain the law.

Being the first to vote he had the opportunity to drive the debate

18 The Attorney General of Justice has a functional independency, the decision to propose a lawsuit before the Supreme Court is a decision which does not need to be approved by another authority.

19 In Brazil the religious faction is very powerful in the Congress, in 2012 they had 63 of the 513 members of the Low House and 3 of the 81 members of the High House. The ones listed here are only declared members of this informal group, though they are very strong before the public opinion (a large portion of the Brazilian people follows a religion, especially of Christian tradition). To be fair, it is almost a miracle the fact that Law 11.105/2005 passed with the text the way it was. 
into a point which was dear to him, he knew that was impossible to ignore the whole controversy about the origin of life ${ }^{20}$. Considering the practical, and theoretical, impossibility of pinpointing the exact moment of the origin of life he choose to lead the discussion to the field of the woman - her freedom about her body and her connection to the fetus.

In order to construct his thought he used the theory of Ronald Dworkin exposed in the book entitled "Life's Dominion: An Argument About Abortion, Euthanasia, and Individual Freedom" . Of his works Dworkin is more well-known by his rights theory ${ }^{21}$ and decision-making theory ${ }^{22}$, and most of his quotations in Brazil revolve around this two theories, however, in this particular case the Justices (not only Justice Ayres Britto) used his moral (in some degree, philosophical) theory which is almost unknown in Brazil.

At first, Justice Ayres Britto brushed aside any doubts concerning potential homicide of fetus, stating, grounded in Dworkin, that the Law protects in different ways the person during his whole life:

"Convergently, the statement that the Law protects life differently in each step of the biological development of a human being is the basis of the thought of Ronal Dworkin, north-American constitutionalist, as it was exposed in his book entitled "Life's Dominion" [the Justice used the portuguese version, but we will bring the quotes of the original]. This protection increases as the human being evolves, and start thickening, in direct proportion of the investment provided in this evolving process: natural investment and personal investment of the parents and family. It can also be called proportional legal protection, in proportion of the amount of investment, that is both a natural and personal investment, since it is a fact that as the progress goes on the frustration, regarding a possible failure, increases (the rising curve of expectation only turn itself in a downward curve with the coming of old age). Check up this elucidating quote: "We believe, as I said, that a successful human life has a certain natural development - conception, fetal development, and infancy- but it then extends into childhood, adolescence, and adult life in ways

20 There are different positions; in general religious positions have a tendency to acknowledge the act of conception as being the very beginning of the human life.

21 Exposed, with more detail, in "Taking Rights Seriously".

22 Exposed, with more detail, in "Law's Empire". 
that are determined not just by biological formation but by social and individual training and choice, and that culminate in satisfying relationships and achievements of different kinds. It ends, after a normal life span, in a natural death. It is a waste of the natural and human creative investments that make up the story of a normal life when this normal progression is frustrated by premature death or in other ways. But how bad this is -how great the frustration-depends on the stage of life in which it occurs, because the frustration is greater if it takes places after rather than before the person has made a significant personal investment in his own life, and less if it occurs after any investment has been substantially fulfilled, or as substantially fulfilled as is anyway likely." 23

By this point of view the fetus, when being a stem cell, does not enjoy full protection, because it is a possible future person, a potential yet undeveloped. Another quote of Dworkin work, to strengthen the notion that the fetus have a development curve in order to fulfill his potential, was made in the footnote 10 of his vote:

"While Saint Augustine (V century A.D) declared himself unsure regarding the existence of the soul since the moment of the conception, Saint Thomas Aquinas (XIII century A.D) 'Catholicism's great thirteenth-century philosopher-saint, Thomas Aquinas, held firmly that a fetus does not have a intellectual or rational soul at conception but acquires one only at some later time-forty days in the case of a male fetus, according to traditional Catholic doctrine, and later in the case of a female'. As Ronald Dworkin said about the author of the Summae Theologiae: 'Aquinas's view about fetal development, which he took from Aristotle, were remarkably prescient in some respects. He understood that an embryo is not an extremely tiny but fully developed child who simply grows larger until birth, as some later scientists with primitive microscopes decided, but an organism that develops

23 Full Sentence, pp. 168-169. 
through an essentially vegetative state, then a stage at which sensations begin, and, finally, a stage of intellect and reason'."24

To connect his argument, and shifting completely the focus of the discussion to the woman, restating the whole bound between woman and fetus:

"It is the excerpt found at page 62-63 [77 in the Portuguese version] of the previously mentioned book "Life's Domain". At the same page that Dworkin resumes the quote of Adriene Rich in order to say that: 'By ignoring the unique character of the relationship between pregnant woman and fetus, by neglecting the mother's perspective and assimilating her situation to that of a landlord or a woman strapped to a violinist, the privacy claim obscures, in particular, the special creative role of woman in pregnancy. Her fetus is not merely "in her" as an inanimate object might be, or something alive but alien that has been transplanted into her body. It is "of her and is hers more than anyone's" because it is, more than anyone else's, her creation and her responsibility; it is alive because she has made it come alive. She already has an intense physical and emotional investment in it unlike that which any other person, even its father, has; because of these physical and emotional connections it is as wrong to say that the fetus is separate from her as to say that it is not'. (...) Actually, a fetus is an organism that, in order to stay alive, needs the continuity of the pregnant woman life. It does not survives on its own. It grows inside a body that also grows with it. Throbs alongside another pulse and also breaths in pair. It does not know what is solitude, because it denies the laws of Physics that two bodies cannot occupy at the same time the same space. If, since its firsts signs of neural formation, it already knows the voice and laughter of whom feeds and carry it, it will bear forever a sentimental bound. Bound impossible to forget! As the man finishes its role in

24 Full Sentence, pp. 198. 
the process of the formation of a new being while in the very act of conception, the woman does not her role with the production of fertilized egg. Similar egg is only the beginning of a internal path that can both lead to life outside, after going through the womb, as it can end, naturally, in a burial urn ('. the terrifying, absolute dying of the light as stated in the clear metaphor of Ronald Dworkin in is important book). ${ }^{25}$

The conclusion of the vote was to sustain the law. Even though the moral theory of Dworkin was used in his argument it is difficult to measure its influence in the decision. The more honest position is to consider it a piece of the argument, but not a major one - the vote will not crumble if we take this argument out of the picture.

In the wake of Justice Ayres Britto others Justices followed. Justice Carmen Lucia, which also voted to sustain the law, followed a similar thought-track. Although similar arguments she only quoted a small phrase of Dworkin, in the footnote 7, in her vote:

"Ronald Dworkin highlights the sanctity of a dignity life, shaping a vast and broad work about its dominion, exposing it as "The second claim that the familiar rhetoric can be used to make is very different: that human life has an intrinsic, innate value; that human life is sacred just in itself; and that the sacred nature of a human life begins, even before the creature whose life it is has movement or sensation or interests or rights of its own. "... If the great battles over abortion and euthanasia are really about the intrinsic, cosmic value of a human life, as I claim they are, then those battles have at least a quasi-religious nature, and it is no part of the proper business of the government to try to stamp them out with the jackboots of the criminal law."26

In all fairness, the quote does not tell us anything new that the common sense itself could not tell (life is important), and does not help us to understand her vote - if it was not there no one would missed it.

25 Full Sentence, pp. 188-191.

26 Full Sentence, pp. 370. 


\section{CASE OF INCONSTITUTIONALITY OF PRESS REGULATION}

In February 27, 2008, the Supreme Court judge the constitutionality of the Press Regulation in the ADPF $\mathrm{n}^{\circ} 130$. This regulation dates from 1967 on the Military Regime in Brazil and established special penalties for journalists, between other authoritarian norms, that intend to restrain press communication.

In a precautionary analysis Justice Menezes Direito ${ }^{27}$ decided to suspended the effects of this law, and consequently, all the judicial demands about it, until a final decision had been taken. Based in Dworkin's work about the relation between the press and the government he voted to suspended the whole press regulation, all while considering its role during the Brazilian dictatorship in the seventies; especially restrained freedom of speech and - here we have Dworkin - the political role of the press (which was suppressed by the press regulation law). When Dworkin talks about the press (possibly thinking about the American press) he claims that it have grown together with the government in a kind of constitutional symbiosis.

"these two institutions have grown in power together, in a kind of constitutional symbiosis: the press has the influence it does in large part because much of the public believes, with good reason, that a powerful and free press is a wise constraint on official secrecy and disinformation. The most basic intention of the framers was to create a system of balanced checks on power; the political role of the press, acting under a kind of limited immunity for mistakes, now seems an essential element of that system, exactly because the press alone has the flexibility, range, and initiative to discover and report secret executive misfeasance, while allowing other institutions in the checks-and-balance system to pursue these discoveries if and as appropriate"

The majority of the Court decided to suspend just some few keynorms in the law (and not the whole law) until the final decision. Over a year later, on April 30,2009, the Court reunited again to issue a final decision in this case.

Justice Ayres Britto, that was reporting the case to the Court ${ }^{28}$ said that freedom of thinking and freedom of expression are legal norms

27 Full Sentence, pp. 21-22.

28 Full Sentence, pp. 61-61. 
much closer of "norms-rules" than of "norms-principles", because its politics and philosophic primacy demanded them to be applied in all situations, independently of its private or public nature.

Justice Menezes Direito ${ }^{29}$, that had mentioned Dworkin before, based his vote on an American case quoted by Dworkin. It was the case New York Times vs. Sullivan about the First Emend. The Brazilian Justice said that "in that decision was created the limitation about the proof for that public agents could receive indemnification, having to proof the existence of "effective malice", namely, the proof that the journalists not only were careless or negligent researching to report, but also that published it knowing it was false or with reckless disregard for truth or falsity of the information it contained". ${ }^{30}$ Based on the vote of Justice Brennan in that case, Justice Menezes Direito understood that often there is a bad placement of information, but stated that it also happens in all kinds of human activities - and when it happens it is possible to require adequate reparation in civil and criminal law. Thus, there is no rational explanation able to justify the existence of a special regulation for the press, which goes hand to hand with democracy, and should not have its role repressed. And so, proclaimed his vote:

"Considering that the actual Press Regulation was born with inspirations incompatible with the constitutional principle of press freedom, in the terms of the reasons I deduced above, I repeat the vote I uttered when voted the precautionary, considering the Law $n^{\circ} 5.250$, from 1967, incompatible with the discipline of the Federal Constitution of 1988."

\section{CASE OF HOMOSEXUAL CIVIL UNION}

At the beginning of this paper we pointed out that, in some of the cases addressed, the Legislative simply did not take part in the discussion, and that the Court took to itself the matter. The most evident, crystal clear of all the cases is the following one (at the moment the last one where Dworkin's work was used) - the case of homosexual civil union.

We also mentioned that in Brazil the religious faction in the Legislative is very strong and have a lot of influence in the public opinion. It seems fairly obvious that the matter of homosexual union is a highly unpopular and contradictory subject, thus the Legislative "ran to the hills" and tried to avoid the problem.

29 Full Sentence, pp. 93-94.

30 Op. cit., p. 331. 
Of course there is a LGBT $^{31}$ community in Brazil, and the approval of homosexual civil union is in their agenda ${ }^{32}$, they also have representatives in the Legislative, but nowhere near as powerful the religious faction. It is needed to say that the LGBT community read correctly the current events and observed that the situation was not a stale-mate, they were losing, in the long-run probably they would win, but it would take a relative large amount of time.

Since the Legislative route lead to a dead-end they turned their attention to the Court, where they had a possibility that their case would be discussed ${ }^{33}$, they (we are encompassing a multitude of NGOs and others amici curiae) proposed the lawsuit in 2008 and the final ruling was issued in 2011.

As it is world-wide, the Court cannot create law, and in Brazil marriage $^{34}$ (civil union status ${ }^{35}$ ), is regulated by law, which also defines what is a family. It would be impossible to plead that the Court instituted the possibility of homosexual marriage, so a constitutional short-cut was found.

The Brazilian Constitution (a very prolific text) itself intends to protect the family, to do so is needed to define what is a family:

Article 226 - The family is the base of the society, enjoying special protection of the State

$\S 3^{\circ}$ - Concerning the effects of the protection of the State, is acknowledged the stable union by a man and woman as a familiar entity, the law must facilitate its conversion in marriage.

$\S 4^{\circ}$ - It is also acknowledged as familiar entity, the community composed by any of the parents and their descendants. (free translation)

The argument of the LGBT community rested upon the 226

31 Initial's of Lesbian, Gay, Bisexual, and Transgender.

32 When we depict the LGBT Brazilian community it looks similar to their counter-parts in other countries, they are, usually, people with higher education and more money than the average person.

33 Since the Court decides its own agenda of judgments it is very possible that a controversial subject is left untouched for a long period of time (sometimes to "cool things down" or simply to never issue a ruling).

34 Implications, legal effects, people who can marry, etc.

35 The status of civil union, and its legal effects, is very similar to the marriage, although different in a formal way, since in this situation the couple does not have a legal document proving their bound. 
article in order to acknowledge that a homosexual marriage (civil union) is a also a familiar entity, and that the Constitution did not exclude this possibility. Nevertheless the text refers only to the traditional union (man and woman), however, it is not the only model possible (as shown in the paragraph fourth of the article 226), thus it is possible to include, via interpretation, another model ${ }^{36}$.

Another argument used is that the Constitution itself stated the equality of rights for citizens ${ }^{37}$ - so there is no justification to deny that the homosexual constitute a family like other citizens, after all the law shall not distinguish, and shall not deny, rights granted to others only because they have a different sexual orientation.

Surprisingly enough, the public opinion did not pose a threat, the opposition was very sparse, and supportive to the claim of the LGBT, in genera ${ }^{38}$. The final decision ruled not only recognized the homosexual marriage (civil union) as a familiar entity, it also granted to them the right to have a civil union ${ }^{39}$ - a awe-inspiring case of unanimous consensus (all the 11 Justices agreed upon the decision, even if deviating about the arguments).

This is a typical atypical case. The Legislative stayed still when a controversial subject arose and put things to a hold due to the lack of political will. The groups interested in a change in the legal system abandoned the Legislative as a forum of public debate due to its lethargy and self-inducing emptiness, and searched for another way. These groups found the Court, willing to promote its own agenda, that in a lot of points coincides with the propositions plead by these groups.

The end of history is always the same, the Court (or the groups interested), create a legal short-cut so as to bypass the Legislative and "solve" the controversy.

Bearing the whole picture in front of us we are able to determine why the work of Ronald Dworkin was used, and its place in the arguments brought to the discussion.

As it was in Bio-security case Justice Ayres Britto was the

36 Considering that the article 226 placed the family in a central place, so important that the State was bound to protect it.

37 Article 5 - Every and all are equal before the law, without distinction of any nature, guaranteeing to the Brazilians and foreigners residents in Brazil the inviolability to the right of life, freedom, equality, security and properties, in the following terms: (...).

38 It is very weird that the same public opinion that elected the officials of the Legislative (both houses) clearly against homosexual marriage found themselves sympathetic to the cause after it was brought to attention of the Court.

39 After the ruling it was decided by the Supreme Court that each State, thorough their own Higher Court, received the task to regulate the procedural steps needed for a homosexual couples to formalize their relationship, thus, in some way, (the formal document is somewhat different) marrying these couples. 
first to vote, but did not make any reference to Dworkin, however the next Justice to vote ${ }^{40}$, Justice Luiz Fux quoted Dworkin in his vote. In general lines the whole argument is about rights, in focus, the right of freedom - approached as a right of equal treatment. During the vote Justice Luiz Fux drafted a conclusion strongly based in a moral reading of the Constitution, as can been seen when we point out that the work quoted was "Freedom's Law: The Moral Reading of The American Constitution".

How we perform the moral reading of the Constitution is a very important question, it is possible that we read the text biased by our own convictions (in some way it is impossible to not be biased). Aligning himself with Dworkin's proposition of moral reading he exposes the almighty principle of this operation: Every and all individual must be treated with equal respect and consideration, in a equality of rights and opportunities.

"We cannot give in, in this case, to considerations of moral order, except for one, that is, by the other hand, indispensable: That all individuals shall be treated with equal consideration and respect. This statement is the basis of the moral reading of the constitution as suggested by Ronald Dworkin (Freedom's Law: The Moral Reading of The American Constitution. Cambridge: Harvard University Press, $p$. 7-8), that, although analyzing the USA constitutionalism, draw conclusions perfectly applicable to the Brazilian constitutional law. I believe that the principles that the principles set out in the Bill of Rights, taken together, commit the United States to the following political and legal ideals: government must treat all those subjects to its dominion as having equal moral and political status; it must attempt, in good faith, to treat them all with equal concern; and it must respect whatever individual freedoms are indispensable to those ends, including but not limited to the freedoms more specifically designated in the document, such as the freedoms of speech and religion. [specially the liberties exposed in the Fourteenth Amendment]. "41

40 In Brazil the order of voting goes this way: The first to vote is the Justice who received the case via a random distribution, afterwards vote the newest member of the Court, the last one to vote is the dean Justice.

41 Full Sentence, pp. 65-66. 
In this first quote is grounded the first base, the needed equality nevertheless, until this point there is no way to explain how this equality will be achieved. Still in Dworkin's wake, the way to make this desired possibility real is through the intervention of the State:

"Still discussing equality, Dworkin, in other book (Sovereign Virtue: The theory and practice of equality), clarifies his point of view about the principle of equality. 'This book's argument- the answer it gives to the challenge of equal concernis dominated by these two principles acting in concert. The first principle requires government to adopt laws and policies that insure that its citizen's fates are, so far as government can achieve this, insensitive to who they otherwise are-their economic backgrounds, gender, race, or particular sets of skills and handicaps. The second principle demands that government work, again so far as it can achieve this, to make their fates sensitive to the choices they have made'. Taking these factors into account, it is impossible to ignore the juridical validity of homosexual stable relationships, it is the same as putting a unjustified disadvantage when comparable to heterosexual stable relationships. The State responsibility is to ensure that the law grants to everyone equality of opportunity, in a way that each individual is enable to live his life autonomously and by his owns purposes, and that sexual orientation does not constitutes an obstacle to the pursuit of personal objectives. The same reason applies, certainly, in all aspects of life and not only to material and professional matters - if known before-hand that subjecting an homosexual to all the embarrassment of being forced to hide a relationship with a partner, or not being able to expect that their relations have any legal effect due to the stable relationship [as it occurs in heterosexual stable relationships] is, without a doubt, a arbitrarily reduction of opportunities. " 42

A characteristic of the Court is that there are two ways of interaction between the Justices, the reading of the vote (others Justices

42 Full Sentence, pp. 66-67. 
can manifest themselves during the reading, requesting the right to speak) and the debates that can occasionally be held (they are not required). While in the discussion, Justice Luiz Fux reinforced his view regarding equality, restating his position.

"[Justice Fux - Oral discussion] Regarding the principle of equality, I gathered two quotes of Ronald Dworkin when he prompts us to perform a moral reading of the constitution - the book titles is Freedom's Law: The moral reading of the American Constitution. What Dworkin says? The government - and we are the government, we practice acts of government too, acts which are inherent to the Public power - if the Legislative does not take action the Court must fill its place. Here considering 'government' as the act of serving as a mediator of the interests of the parties, that did not arrive, by a friendly discussion, in a agreement. As Dworkin states: 'I believe that the principles that the principles set out in the Bill of Rights, taken together, commit the United States to the following political and legal ideals: government must treat all those subjects to its dominion as having equal moral and political status; it must attempt, in good faith, to treat them all with equal concern; and it must respect whatever individual freedoms are indispensable to those ends, including but not limited to the freedoms more specifically designated in the document, such as the freedoms of speech and religion.] - specially the liberties exposed in the Fourteenth Amendment. In a another work, more recent, 'Sovereign Virtue: The theory and practice of equality', Dworkin highlights that: 'This book's argument- the answer it gives to the challenge of equal concern- is dominated by these two principles acting in concert. The first principle requires government to adopt laws and policies that insure that its citizen's fates are, so far as government can achieve this, insensitive to who they otherwise are-their economic backgrounds, gender, race, or particular sets of skills and handicaps. The second principle demands that government work, again so far as it can achieve this, to make their fates sensitive to the choices they have made'. 
It is verified, under the perspective of equality, that the recognition of stable homosexual relationships is a logical conclusion extracted from the articles of the Constitution, it is a respect held in consideration to the Constitution." 43

The final decision was unanimous, so it is very complicated to ponder how much impact the work of Dworkin had, it can be said that it was very relevant, the notion of moral reading was used to steer the argument and gave it a theoretical base to justify the proposition of constitutional interpretation. Another point to strengthen its relevancy is that, since (even being the second to vote) Justice Luiz Fux shaped the final decision in a way that others Justices followed. However, having said that, every Justice's vote have a personality, although, in this case, the discussion revolved (most of the time) around equality of treatment and freedom.

Of course, it is impossible to mathematically measure the impact of Dworkin (since we delve on area of arguments, by definition a nonexact area). On the other hand, it is fully possible to perceive that it was, of all the cases, the one which Dworkin work had the most influence in the construction of the argument and usage of relevant quotes.

\section{CONCLUSIONS}

Although recent in Brazil, Dworkin's philosophy become vastly known - and reached the Supreme Court precisely in a changing-time of its institutional role. The most discussed issue on Dworkin's philosophy is the method suggested in Taking rights seriously. Surprising, the Supreme Court used his moral and political work that is less known in the country, but served best for the purposes of these cases judgments - all hard cases that demanded moral and political positions of the Justices. Brazilian Supreme Court embrace Dworkin philosophy for improve its own political role by extending legal interpretation to offer solutions on institutional crisis and social claims.

\section{REFERENCES}

Dworkin, Ronald, LIFE'S DOMINION: AN ARGUMENT ABOUT ABORTION, EUTHANASIA, AND INDIVIDUAL FREEDOM, New York, Vintage Books, July 1994.

Dworkin, Ronald, SOVEREIGN VIRTUE: THE THEORY AND PRATICE OF EQUALITY, London, Harvard University Press, 2002.

43 Full Sentence, pp. 80-81. 
Dworkin's Philosophy on the Supreme Court - Luciano Del Monaco and Nuria López

Dworkin, Ronald, TAKING RIGHTS SERIOUSLY, Cambridge, Massachusetts, Harvard University Press, 1978.

Vilhena, Oscar. SUPREMOCRACIA in Revista Direito GV, n08, JulDec/2008, p.443. 